\title{
ARCO E FLECHA APYÃWA
}

Arawyo Tapirapé

Professor Alfabetizador da Ação 'Saberes Indígenas na Escola'

\section{RESUMO}

XEPARAMA'EÃWA KOME'OWÃWA. Te'omara kwee aapa weparama'ewo Myryxitajpe wexemima'e agy ramõ. Iypy ramõ kwee akome’o py ma'e re arate'omamataãwa pitywera agy we. Akome’o kwee eixope o’ywa ma’era aoxekato imagyãwa, marygato iapaãwa xereparawykãjmo. A' eramõ kwee araxe'egenop awaxewete aratajpe wãra mõ. A' e kwee emikome’o arakwaxiãt ywyrape pe xerexe'egimõ: ipiraeawãra, xawewyraxi, yrwo'ywa, koropiwã, akamaxywypyo'ywa, orowiaxio'ywa, o’ykawã, koõ pe wãra. Pity wera we, ipoenokatokatoakãta ixope ee te'omare'yma we. Ee a'e ramõ xeremima'e agy tanemejxe ipowenowi o’ywa paragetã.

PALAVRAS-CHAVE: Alfabetização. Letramento. Contextualização.

O tema que foi desenvolvido com os meus alunos foi realizado na sala anexa da aldeia Myryxitãwa. Iniciando, trabalhei com nosso tema "arco e flecha". Apresentei aos alunos, explicando a importância do uso e a forma de fazer, de acordo da nossa realidade. Nesse momento pedi para cada aluno falar sobre o tema "arco e flecha". Seguindo os trabalhos, fizemos a entrevista com os mais velhos da nossa comunidade, para produzir os materiais em alfabetização e letramento.

Continuando, listamos os nomes de flechas em língua materna como: ipiraeawãra, xawewyraxi, yrywo'ywa, koropiwã, akamaxywypyo'ywa, orowiaxio'ywa, o’ykawã, koõpewãra. Trabalhamos o tema de forma transdisciplinar, usando o desenho abaixo, sobre Ywyrapãra 'arco', nosso tema geral.

Antes de fazer os trabalhos, comentei com os alunos que o nosso povo Apyãwa fazia esses tipos de flechas para caçada, pescaria, para sua defesa e até mesmo para se identificar como o povo Apyãwa. 
É muito importante a explicação deste tema para os alunos, porque eles precisam entender o que é mesmo a flecha para nós do povo Apyãwa.

Através da contextualização, tanto na teoria quanto na prática, os alunos vão facilitar os seus conhecimentos, fortalecendo as regras de uso e a história. Por isso as entrevistas dos mais velhos da nossa comunidade são muito importantes, porque eles são nossas bibliotecas, onde coletamos os conhecimentos para atualizar, de acordo com a nossa realidade, para os nossos jovens e para as futuras gerações.

Solicitei aos alunos para ilustrarem os tipos de flechas no

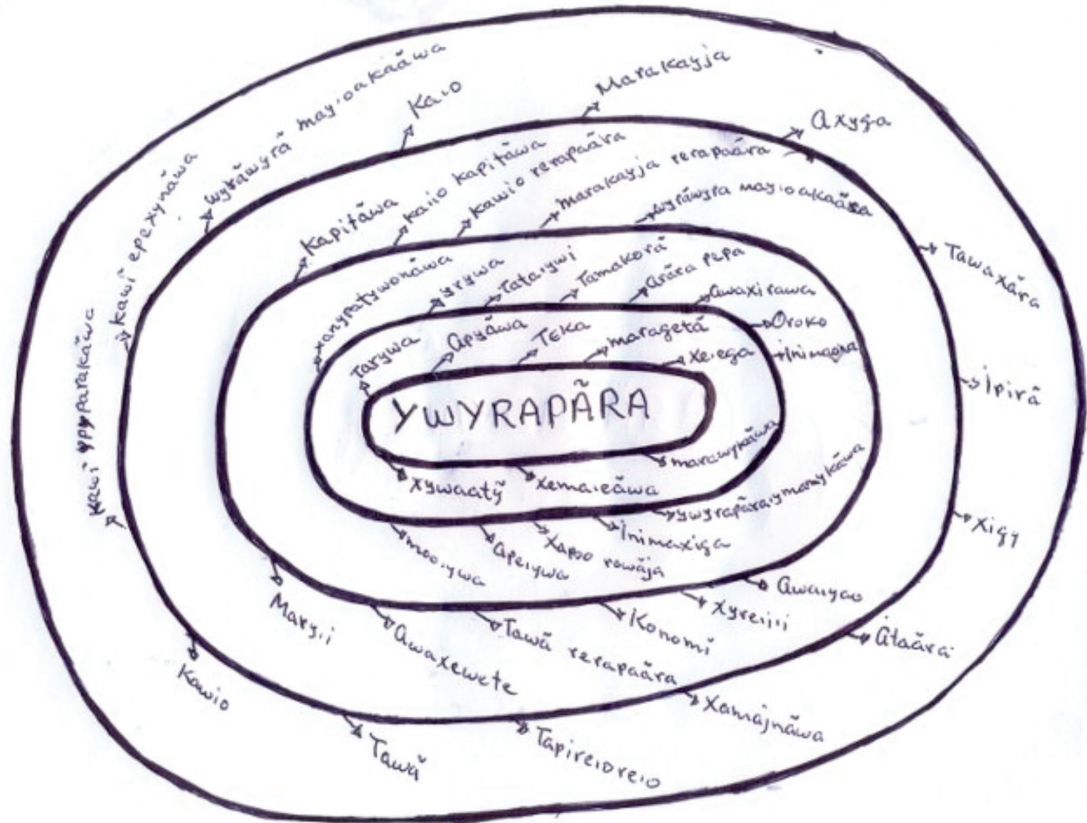

papel Chamex, para depois escreverem os nomes em cada peça. Depois disso fizemos outros desenhos, separando de parte em parte, para os alunos entenderem os nomes de cada peça que usamos na flecha.

Terminando a ilustração da flecha, nós escrevemos juntos os nomes de cada peça de flecha em escrita Apyãwa, para os alunos irem lendo ou conhecendo através do desenho. Fizemos o círculo para 
os alunos fazerem a leitura individual, explicando o que já tinham entendido e o que entenderam nesse momento através deste tema.

Terminando as atividades, fizemos uma pequena avaliação com os alunos sobre o que entenderam dentro desse tema. Se os trabalhos contribuíram com a aprendizagem deles e o que eles queriam aprender mais. Cada aluno citou a sua opinião avaliando o meu trabalho e nosso tema trabalhado. Finalizando a avaliação do nosso trabalho, expliquei um pouco o meu objetivo, para que estou trabalhando com eles sobre a arco e flecha.

O meu objetivo com esse trabalho foi ensinar os estudantes sobre esses conhecimentos do nosso povo, para que eles também venham conhecendo e praticando esses valores que nós temos sobre arco e flecha. Então, em primeiro lugar, eu ensinei os alunos no conhecimento que conheço referente à flecha. Depois disso trabalhei com eles sobre aquilo que o senhor entrevistado Awaetekato'i nos informou. Através da observação e comentário da prática realizada, os alunos ajudaram bastante a compreender esse conhecimento do arco e da flecha do nosso povo Apyãwa. Entendemos que eles estão muito relacionados à natureza e à nossa cultura.

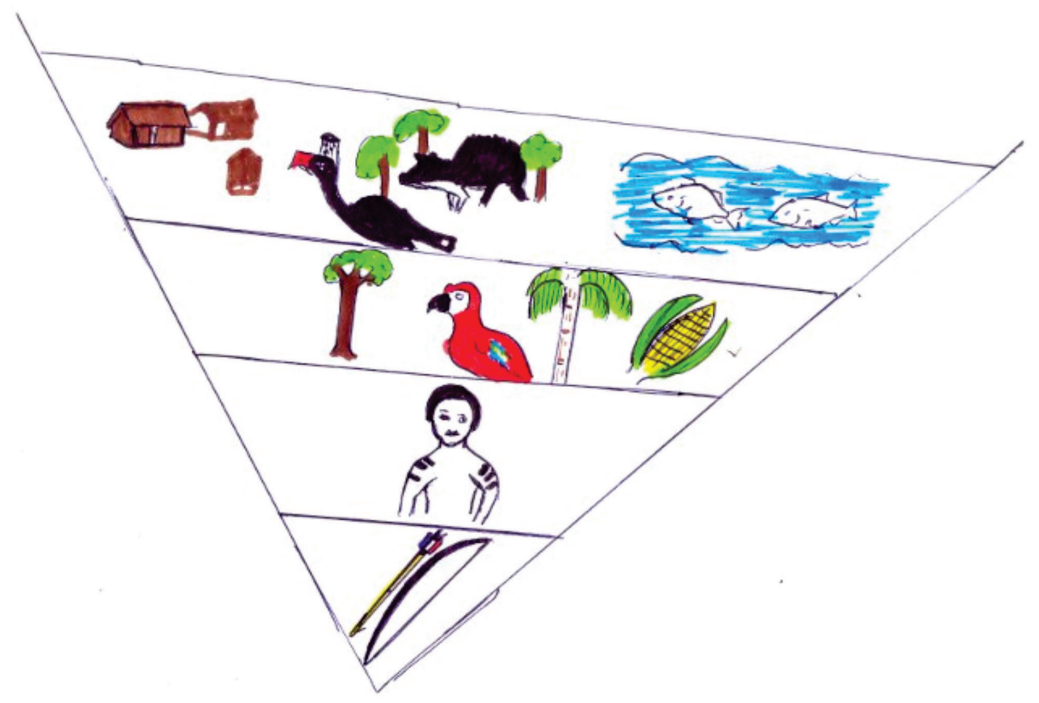

\section{REFERÊNCIAS}

TAPIRAPÉ, Awaetekato’i. Arco e flecha Apyãwa. Entrevista. Aldeia 
Myryxitãwa, 2014. 